\title{
ARSITEKTUR VERNAKULAR NABIRE DAN KONDISI NABIRE PASCA GEMPA
}

\author{
L.M.F. Purwanto dan C. Sri Gayatri \\ Staf Pengajar Jurusan Arsitektur Fakultas Teknik Universitas Katolik Soegijapranata Semarang \\ Email: purwanto@gmx.de
}

\begin{abstract}
ABSTRAK
Pada saat bencana alam di Nabire yang terjadi Februari 2004 dan November 2004, banyak bangunan roboh dan rusak. Kerugian sangat besar dan mengakibatkan kerugian baik material maupun keselamatan manusia. Kerusakan yang parah sering diakibatkan oleh salahnya penerapan konstruksi dan salah dalam pemilihan bahan bangunan. Sementara itu pasca bencana, menyisakan kesulitan berupa lamanya membangun bangunan penampungan korban bencana, sehingga seringkali korban bencana hanya ditampung di tenda saja. Akibatnya muncul masalah sosial dan kesehatan. Bangunan yang roboh juga membutuhkan waktu yang lama untuk dibangun kembali. Hal ini mendorong pemikiran untuk mengembangkan rumah cepat bangun yang dapat diterima masyarakat, pada saat bencana telah berlalu. Pada penelitian tahun I ini, dilakukan pengumpulan data tentang arsitektur tradisional dan arsitektur vernakular di Nabire, untuk memahami secara lebih dekat segala permasalahan yang harus dihadapi dan potensi yang dapat dikembangkan untuk membangun rumah Rakyat. Penggalian arsitektur vernakular, diharapkan tidak hanya mendekatkan rumah tinggal yang akan dibangun kembali nantinya, sesuai dengan segala aktifitas dan budaya masyarakat setempat, namun juga untuk lebih mudah dipahami dan mudah dikerjakan sendiri oleh masyarakat, karena bentuk konstruksi dan arsitekturnya sudah menjadi bagian dari kehidupan mereka.
\end{abstract}

Kata kunci: arsitektur tradisonal, vernakular arsitektur, gempa di Nabire.

\section{ABSTRACT}

The natural disaster in Nabire in February 2004 and November 2004 has left a noumerous effects on buildings. Many buildings have destroyed because of the terrifying effect of natural disaster which caused a big loss both for material and for the human safety. However, the misapplication of construction and inappropriate choice of material almost cause the terrible damage. After the natural disaster passed, the only left is mostly on the long time needed to build the buildings for people who suffer from the disaster. Because of this problem above, many people usually stay in uncomfortable places such a tend, and this condition creates social and health problems. Concerning the problem above, it is needed to create the "quick built house" which is hopefully can be accepted by the community to cope with the terrifying effect of the natural disaster.In the first year of this research, the data concerning traditional architecture and vernacular architecture in Nabire will be collected. This step will be done in order to understand more detail about all the problem faced and identified all the potential aspects which can be developed to build house for people. The deepest study of vernacular architecture is expected not only to make the house close to the uniqueness of the local activities and culture, but also to make it understandable and built easily by the people/community, because its construction and architecture have become part of their life.

Keywords: traditional architecture, vernacular architecture, Earthquake in Nabire.

\section{PENDAHULUAN}

Pada saat terjadi gempa di Nabire pada bulan Februari 2004 dan November 2004, banyak rumahrumah penduduk yang hancur. Kendala dari bencana alam, selalu adalah kekurangan penyediaan rumah tinggal yang memadai. Akibatnya para pengungsi harus lama tinggal di tenda penampungan. Tuntutan pembangunan rumah penampungan bencana dan perbaikan rumah akibat gempa menjadi mendesak dan harus segera direalisasikan, jika tidak penyakit akan muncul. Sementara itu, pembangunan rumah penampungan, juga harus memperhatikan aspek manusia sebagai penghuninya. Lokasi gempa harus diperhatikan. Aspek manusia sebagai penghuni mencakup bentukan ruang, arsitektur, kebiasaan hidup, budaya, religi, adat dan kesenian. Namun yang terpenting masalah kebiasaan hidup dan arsitektur tidak dapat diabaikan begitu saja. Dengan memperhatikan dua aspek tersebut pendekatan untuk memanusiakan dan mengakui keberadaan masyarakat tersebut dapat tetap terjaga. Rumah yang dibangun akan dapat benar-benar diterima oleh masyarakat korban gempa di daerah tersebut.

Irian Jaya sebagai propinsi paling timur di Indonesia juga merupakan daerah vulkanik dan tanah muda. Pergeseran lempengan masih terus berlangsung sampai mendapatkan kestabilan sebagai tanah matang atau tua. Sementara itu jumlah masyarakat tradisional masih mayoritas dengan pendidikan yang masih rendah. 
Sementara itu, dengan mencermati Program Transmigrasi oleh pemerintah semasa Orde Baru, mengakibatkan terjadinya banyak pergeseran bentuk arsitektur. Sistem pemerintahan di era orde baru dimana pejabat daerah banyak didatangkan dari Jawa menyebabkan arsitektur Jawa (Joglo) banyak dijumpai di kota-kota Irian termasuk Nabire. Rumah transmigran yang memakai bentuk arsitektur masa kini banyak mendominasi Nabire. Hal tersebut mempengaruhi pola berpikir/selera masyarakat asli. Akibatnya bentukan rumah baru masyarakat asli yang bertempat tinggal di Nabire banyak dipengaruhi bentuk baru, disamping terjadi pergeseran atau penyederhanaan dari bentuk asli masing-masing etnis ketika mereka berpindah ke Nabire.

\section{METODE PENELITIAN}

Nabire sebuah tempat rawan terhadap bencana alam berupa gempa bumi. Gempa pada tahun 2004 menyisakan beberapa bangunan yang belum tertangani dengan baik. Sementara itu di sisi lain, kebijakan dan pendekatan pemerintah dalam penanganan penyediaan rumah, belum menyentuh hal-hal mendasar yang mendekatkan penghuni dengan bangunannya. Keterlibatan masyarakat Nabire dan tuntutan normatif belum dilakukan. Maka penelitian ini dilakukan dengan berangkat dari pendataan masalah di kota Nabire, seperti: interaksi masyarakat Nabire dengan pendatang (para transmigran), kebijakan pemerintah dalam pengadaan perumahan, baik pra maupun pasca gempa, keinginan membangun masyarakat, adat dan arsitektur yang masih dipertahankan serta bentukan arsitektur vernakular. Semua itu didata baik melalui pendataan primer maupun sekunder. Data primer dilakukan dengan wawancara dan peninjauan langsung ke pemukiman suku Moni dan Mee. Pendokumentasian dilakukan dengan pemotretan dan penggambaran sketsa rumah. Sementara data sekunder dilakukan dengan mengumpulkan data dari instansi pemerintah, seperti Bappeda, Badan Pusat Statistik dan Dinas Pariwisata. Setelah semua data diperoleh, maka disusun sebuah dokumentasi pendataan yang menggambarkan bentukan arsitektur tradisional, arsitektur vernakular dan kondisi masyarakat pasca gempa untuk dikelola sehingga dapat dijadikan landasan/input untuk simulasi komputer di tahun II.

\section{PEMBAHASAN}

Sejak manusia beralih cara hidupnya, dari berburu dan memungut beralih ke usaha budi daya, mereka mulai menetap dan mengenal bentuk rumah, berawal dari rumah ranting yang berbentuk kerucut dengan atap yang langsung menempel di tanah yang lebih dikenal dengan sebutan Adam's House atau gubuk Adam. (Waterson, R., 1990) atau bentuk lain berupa rumah pohon, yaitu gubuk yang dibangun di atas pohon untuk mengantisipasi gangguan binatang dan musuh.

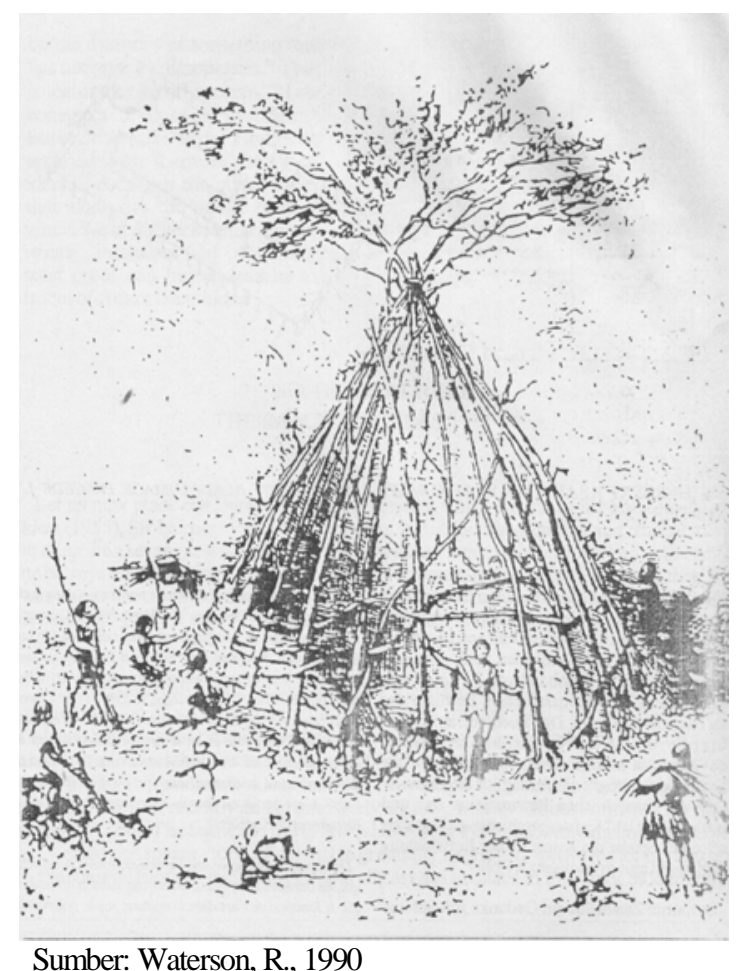

Gambar 1. Adam's house

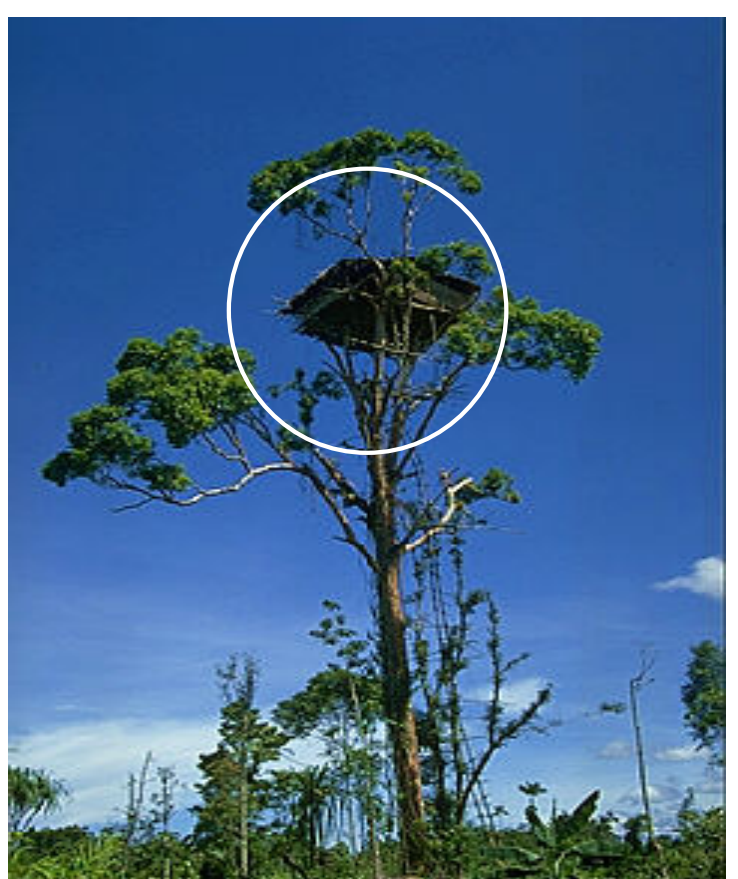

Sumber: Dokumentasi Jemi Pigome, 2005.

Gambar 2. Rumah Pohon 
Menurut Rapoport (1969) yang menyoroti dari sisi prosesnya menyebutkan bahwa vernakular adalah salah satu proses yang didasarkan pada model dan variasi. Variasi diperoleh dari pengembangan (pengkayaan) dari satu model. Lazimnya dimulai dari bentuk-bentuk sederhana, unsur-unsur utama bangunan yang kemudian diperkaya, dielaborasi detail-detailnya untuk membuat pengaturanpengaturan selanjutnya. Dengan demikian bangunan vernakular didasarkan pada ide-ide yang sangat dipahami oleh masyarakatnya. Perubahan-perubahan kecil terjadi tetap dalam satu kerangka yang disepakati dalam suatu masyarakat tertentu.

Karakter selanjutnya dari vernakular adalah dalam hal kemampuan pengembangannya. Pengembangan ini tidak hanya menyangkut penambahanpenambahan bangunan, namun juga dalam hal tampilannya. Vernakular juga dicirikan dengan besarnya perhatian pada hubungan antar bangunan dalam satu lingkungan, yang nantinya sebagai dasar pertimbangan-pertimbangan dalam perencanaan lingkungan binaan.

Arsitektur vernakular ${ }^{1}$ merupakan transformasi dari situasi kultur homogen ke situasi yang lebih heterogen dan berusaha sebisa mungkin menghadirkan citra, bayang-bayang realitas arsitektur tradisional. Rasa hormat pada tradisi "agung" dan "tinggi" biasanya cukup nyata pada arsitektur vernakular. Citra yang disajikan lebih banyak bersandar pada referensi arsitektur "rakyat" daripada terhadap bangunan keagamaan, bangunan milik bangsawan-penguasa dan sejenisnya. Referensi pada arsitektur "rakyat" yang secara fungsional sudah beradaptasi, jitu, teruji terhadap alam tempatnya berada, biasanya lebih memiliki kepekaan baik secara teknis, sosial, dan kultural. (Sutanto, S.,2001 )

Sementara itu menurut Rapoport (1969) pengertian tradisional didasarkan pada suatu kesepakatan tentang model bangunan yang diwariskan melalui beberapa generasi tanpa terjadi perubahan-perubahan yang cukup signifikan. Menurunnya eksistensi arsitektur tradisional lebih banyak disebabkan oleh kompleksitas fungsi-fungsi

\footnotetext{
${ }^{1}$ Pengertian arsitektur vernakular menurut Collins Cobuild Dictionary adalah : “A vernacular architecture is a style of architecture in which ordinary people's houses are built, for example using local building materials and having low ceilings, rather than copying the grand architecture of palaces and churches”. Sementara itu menurut Oxford Advanced Learner's Dictionary(1989) vernakular berarti: "Language or dialect spoken in a particular country or region, as compared with a formal or written language”. Dari pengertian diartikan bahwa vernakular berkaitan aspekaspek lokal (bahan bangunan, iklim, norma dsb), simple/ pragmatis
}

bangunan yang semakin tinggi dan tidak mungkin lagi diselesaikan sesuai dengan kaidah-kaidah membangun tradisional. Di samping itu semakin menurunnya sistem nilai dan pandangan masyarakat yang disepakati termasuk dalam hal bentuk maupun model-model arsitekturnya. Sebagai regulator informal tradisi tidak lagi hidup di dalam masyarakat modern yang membebaskan masyarakat memilih dan menggunakan bentuk-bentuk yang baru. Arsitektur tradisional lekat dengan tradisi yang masih hidup, tatanan, wawasan, dan tata laku yang berlaku sehari-hari secara umum.

Secara umum jumlah masyarakat tradisional masih mendominasi Papua yang artinya rumah tradisional vernakular masih banyak tersebar terutama di pedalaman. Di kota pada umumnya sudah terjadi pergeseran, arsitektur vernakular tradisional mulai berubah. Hal tersebut dikarenakan banyak faktor diantaranya faktor luas lahan, perubahan cara hidup misal karena persebaran/ pengenalan agama maka poligami mulai ditinggalkan, perpindahan mata pencaharian dari agraris ke perdagangan, pergeseran budaya karena adanya komunikasi budaya dengan para transmigran dsb. Demikian pula dengan Nabire yang merupakan bentukan kota baru dalam artian bahwa tidak ada dapat disebut sebagai penduduk asli Nabire. Pada umumnya masyarakat asli Papua yang hidup di Nabire terdiri dari banyak etnis yang berasal dari banyak tempat di Papua, selain transmigran Jawa. Mereka pada umumnya hidup berkelompok sesuai etnis masing-masing, namun bentukan arsitekturnya senada, yaitu bentukan masa kini. Hal ini banyak dipengaruhi bentukan rumah baru yang dibangun oleh pemerintah yang diperuntukkan bagi transmigran. Perbedaan baru terlihat ketika masuk ke dalam rumah. Tata ruang dalam rumah masyarakat asli biasanya akan dijumpai ruang laki-laki dan ruang perempuan dan ruang komunal disamping ruang makan dan dapur.

\section{Asal Mula dan Sejarah Suku Bangsa Nabire}

Nabire karena letaknya yang strategis kabupaten ini, sejak dahulu kala telah merupakan satu wilayah pembauran antara suku bangsa baik yang berkelana melalui laut ataupun darat serta mereka yang bertani dan memiliki penghuni tetap. Telah terjadi kontak antara suku di pulau dan pesisir pantai, daerah aliran sungai dan rawa, dataran rendah, perbukitan hingga pada daerah pegunungan terjal. Kontak yang terjadi baik melalui adu kekuatan dalam permusuhan seperti perang, perampokan, penangkapan budak, pengusiran maupun dalam kesepakatan damai seperti pesta dan perkawinan antar suku serta pembagian kawasan dan lahan olahan. 
Dari data lapangan yang sempat diperoleh terdapat lebih kurang 3 kultur wilayah olahan yang membentuk kelompok kekerabatan yaitu:

1. Kepulauan, pesisir pantai, rawa dan muara aliran sungai

2. Dataran landai dan perbukitan serta batang aliran sungai

3. Dataran tinggi dan pegunungan terjal.

Untuk kawasan pulau dan pesisir pantai, kawasan rawa dan muara sungai dapat disebutkan suku-suku Yaur, Yeresiam, Moor-Mambor, Napan Weinami. Kawasan daratan landai dan perbukitan serta batang aliran sungai Suku Taronggarei dan suku Jabi di bagian barat pegunungan Weyland. Untuk kawasan dataran tinggi dan pegunungan terjal ke arah sebelah timur lereng gunung Weyland terdapat kelompok Mauka atau yang dikenal dengan nama suku- suku Mee, Moni, Damal dan Dani. Kontak yang terjadi antara suku yang telah berlangsung sejak dahulu itu dengan sendirinya telah pula menghendaki adanya berbagai perlakuan budaya termasuk dalam hal ini tatanan adat istiadat serta tata aturan adat yang diberlakukan didalamnya.

Ada komponen baru yang timbul dalam keturunan misalnya fusi Yaur-Yeresiam atau splitsing, maka terjadi pemecahan dari Mor menjadi MorMambor dan Napan Weinami. Selain itu terjadi pula perkawinan campur, sehingga timbul tunggul baru kekerabatan misalnya antara Mor Mambor, Napan Weinami dengan Taronggarei terjadi kelompok Wanaha, demikian seterusnya dapat terjadi berbagai kemungkinan.

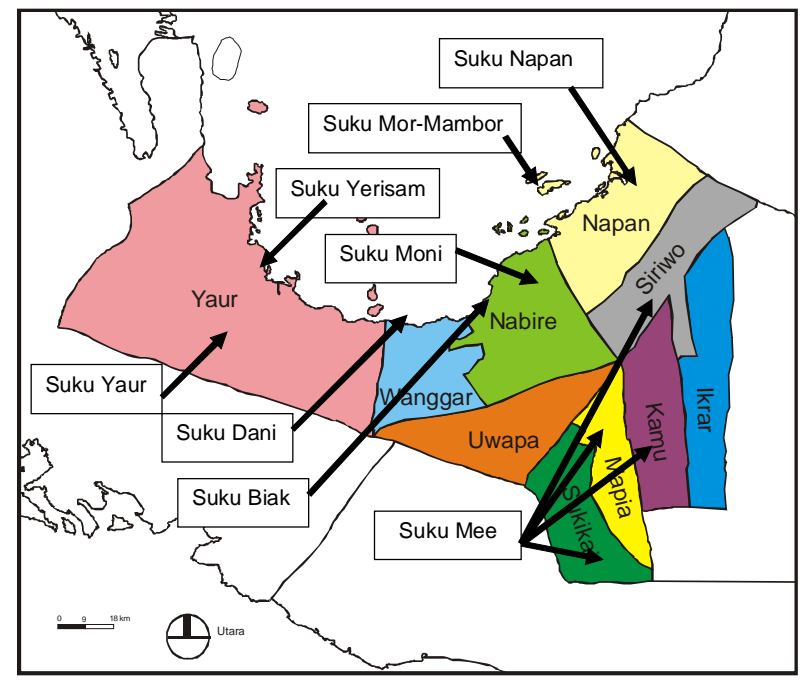

\section{Gambar 3. Peta sebaran suku-suku di Nabire}

Dari perpaduan ini, maka secara fisik dapat dikatakan ada tiga ras manusia penduduk asli Irian Jaya di Nabire yaitu “ Ras Papua- Negroid” untuk penduduk kawasan lereng landai dan pedalaman- pegunungan "Ras Papua-Melanoid” untuk kawasan pulau dan pesisir pantai serta "Ras Campuran” yang terjadi karena paduan antara keduanya dan termasuk perkembangan terakhir kawin campur dengan kelompok dari bagian Indonesia lainnya.

\section{Permasalahan yang Dialami Masyarakat Nabire}

Nabire dan masyarakat Irian Jaya pada umumnya, mula-mula hidup dalam adat, kebiasaan, hukum dan budaya yang khas dan unik. Mereka hidup dalam satu dunia yang belum mengenal budaya menulis. Peninggalan-peninggalan berupa catatan lontar, tulisan di gua-gua dsb belum mereka kenal. Dapat dikatakan mereka hidup dalam era pra sejarah (Jaman dimana manusia belum mengenal tulisan). Kehidupan mereka tidak berevolusi dari era pra sejarah menuju era sejarah dengan tahapan-tahapan sebagaimana sejarah manusia pada umumnya. Namun terjadi loncatan yang sangat cepat. Akibatnya terjadi konflikkonflik dengan para pendatang. Permasalahan yang dialami antara lain:

1. Pemerintah kolonial Belanda dan para misionaris memperkenalkan budaya baru, yaitu hidup di dalam rumah dan berpakaian selayaknya masyarakat Barat. Akibatnya permasalahan kenyamanan klimatologis mulai bergeser

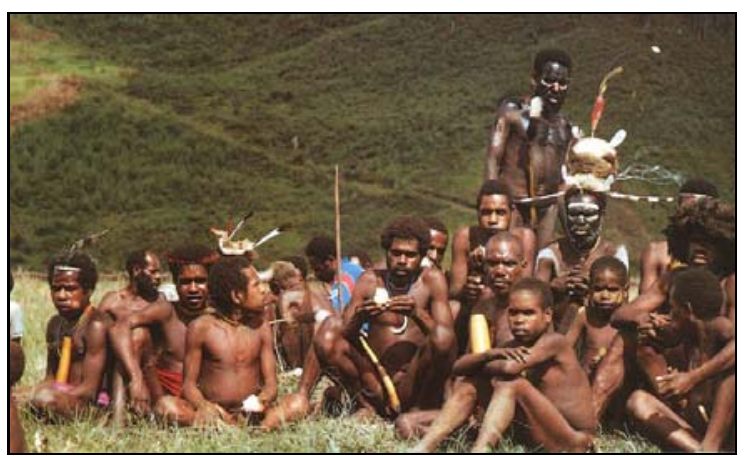

Sumber: http://www.etm.pdx.edu/htliono/images/p190.jpg)

\section{Gambar 4. Masyarakat Dani dengan pakaian tradisional yang cocok dengan iklim tropis}

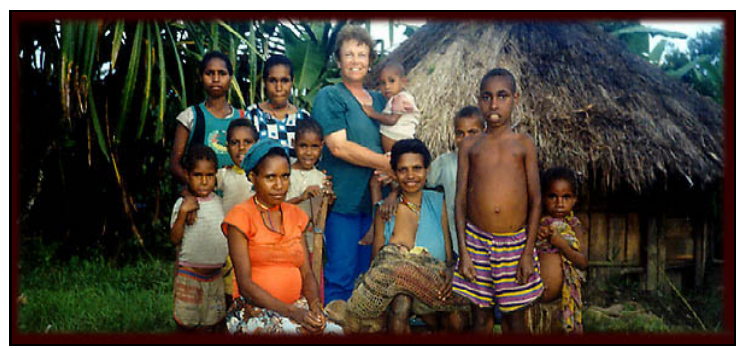

Sumber: http://www.ritagoldengelman.com/images/irianjaya family.jpg)

\section{Gambar 5. Masyarakat Dani dengan Pakaian} Modern 
2. Di era Orde Baru, perluasan wilayah yang dilakukan dengan transmigrasi memunculkan benturan antara hukum normatif dan hukum adat. Hukum normatif menyatakan bahwa Irian Jaya merupakan bagian dari wilayah kenegaraan dan penguasaan tanah harus diatur melalui sertifikat tanah. Sementara hukum adat mengatur kepemilikan tanah dengan cara mereka sendiri. Karena tanpa sertifikat, maka pemerintah menganggap tanah yang ada adalah tanah negara yang dapat dikelola dengan utuh tanpa memperdulikan hukum adat tersebut. Akibatnya memunculkan konflik antara para transmigran yang dilengkapi dengan sertifikat dengan para penduduk asli yang mempertahankan tanahnya melalui hukum adat

3. Pergeseran arsitektur tradisional Irian Jaya menuju arsitektur Jawa melalui program transmigrasi dan kepemimpinan daerah oleh orang Jawa di Era Orde Baru. Pertahanan Budaya yang lemah dari masyarakat Irian Jaya karena belum dikenalnya dokumen sejarah dan budaya tulis, mempercepat hilangnya budaya dan arsitektur setempat

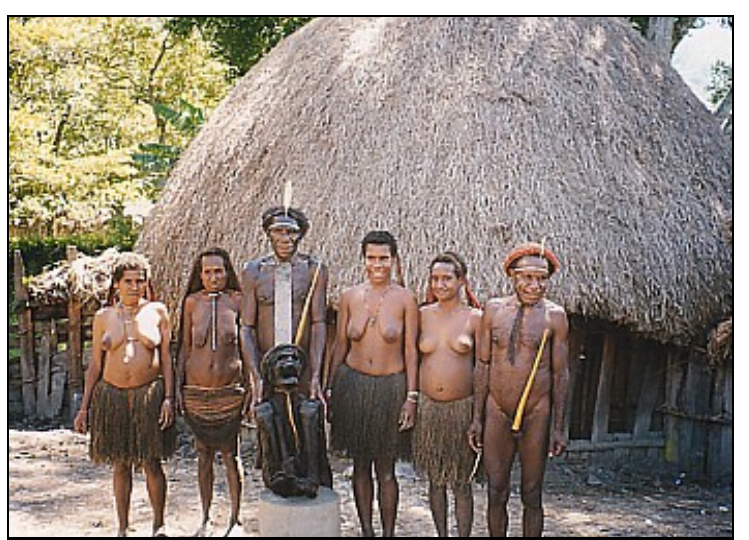

Sumber:http://www.merelyscene.com/irian/image/mummy1. papua.jpg

Gambar 6. Masyarakat Dani di depan Honai

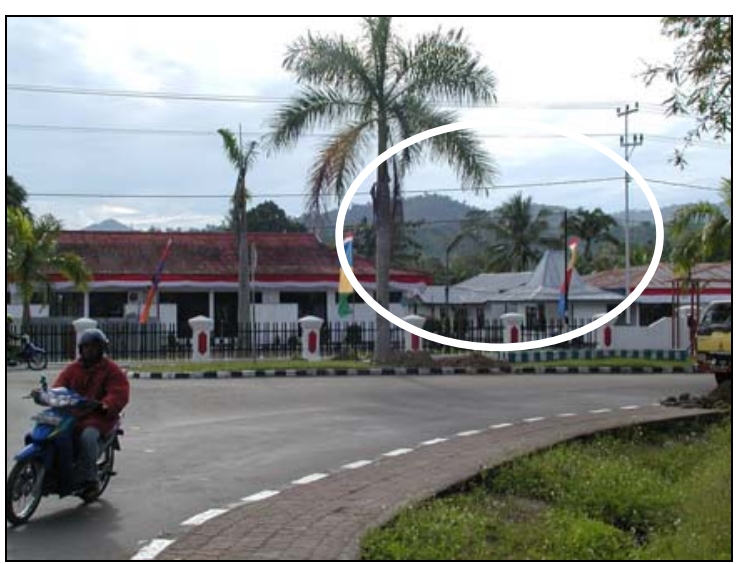

Gambar 7. Joglo di Nabire

4. Gegar Budaya terjadi karena cepatnya arus informasi dan teknologi tanpa diikuti dengan pendampingan mental, intelektual dan pendekatan sosial yang memadai. Akibatnya terjadi kontradiksi antara perilaku yang masih primitif dengan lingkungan yang modern

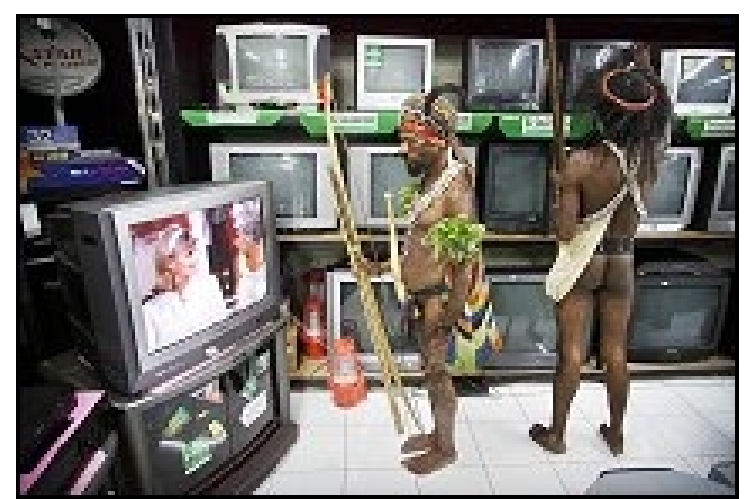

Gambar 8. Orang Mee berpakaian tradisional di sebuah toko elektronik

Akibat hal tersebut, jejak-jejak arsitektur tradisional perlu direkonstruksi dan dipertahankan, baik secara utuh menyeluruh maupun sebagian disesuaikan dengan keinginan, kemauan dan kemampuan masyarakat Nabire khususnya, dan masyarakat Irian Jaya secara umumnya. Sebagian masyarakat Nabire membangun bangunannya dengan pola tata ruang menurut bangunan tradisional, namun tampilan bangunan tidak lagi mencerminkan bangunan tradisional Irian Jaya.

\section{Arsitektur Vernakular Nabire}

Nabire karena letaknya yang strategis kabupaten ini, sejak dahulu kala telah merupakan satu wilayah pembauran antara suku bangsa baik yang berkelana melalui laut ataupun darat serta mereka yang bertani dan memiliki penghuni tetap. Telah terjadi kontak antara suku di pulau dan pesisir pantai, daerah aliran sungai dan rawa, dataran rendah, perbukitan hingga pada daerah pegunungan terjal. Kontak yang terjadi baik melalui adu kekuatan dalam permusuhan seperti perang, perampokan, penangkapan budak, pengusiran maupun dalam kesepakatan damai seperti pesta dan perkawinan antar suku serta pembagian kawasan dan lahan olahan.

Tanah dipandang orang Mee seperti ibu, pemberi kehidupan. Kepemilikan tanah biasanya secara komunal atau kepemilikan bersama. Dari kepemilikan bersama baru dibagikan kepada keluarga-keluarga untuk diolah. Orang Mee mengerti betul batas-batas hak ulayatnya, karena itu tidak ada sejengkal tanahpun yang kosong atau tak bertuan. Kepemilikan diwariskan kepada turunannya. Karena tanah dipandang sebagai ibu oleh masyarakat Mee, maka tanah tidak diperjualbelikan. Masyarakat hanya mempunyai hak pakai. Masyarakat Mee membagi wilayahnya atas: 
a. Mude, areal tanah garapan untuk kebun keluarga.

b. Gamouda, hutan yang ditumbuhi pohon penng bermutu untuk pembuatan perahu, papan rumah. Areal ini juga ditumbuhi rotan sebagai bahan pembangunan rumah keluarga

c. Buguwa, Hutan rimba yang dimiliki secara bersama. Tempat ini merupakan tempat untuk berburu. Selain tempat berburu juga sebagai areal pertumbuhan bahan rotan

d. Bega adalah tanah di puncak-puncak gunung yang tidak berhutan. Tanah ini milik klen tertentu dan dianggap sebagai tempat yang keramat.

e. Rawa adalah tanah berair dan berlumpur yang terletak di lembah-lembah. Dimiliki secara kolektif dan merupakan tempat mencari ikan.

Dengan membagi wilayah pada fungsi tertentu akan menjaga keberadaan tanah tersebut. Mereka menjaga tanah dengan ketat terutama secara ritual. Setiap jengkal tanah disucikan dengan ritual-ritual secara periodik. Sistem kekerabatan patrilineal, dengan pola permukiman keluarga secara patrilokal. Pembagian tanggung jawab antara pria dan wanita tetap jelas. Wanita tugasnya menjaga kelangsungan hidup keluarga, dengan menjadi tulang punggung ekonomi keluarga, sementara laki-laki menjaga martabat, aturan adat dsb. Pembagian tanggung jawab ini tercermin pada pola ruang dalam rumah. Dapat dilihat bahwa ada ruang laki-laki dan ada ruang perempuan. Perempuan tidak dibenarkan masuk kedalam ruang laki-laki. Pemisahan kandang babi dari rumah utama juga merupakan bentuk perkembangan rumah vernakular mereka. Pada suku Mee yang masih tinggal di pedalaman babi akan hidup bersama dalam satu rumah dengan perempuan. Babi menjadi tanggung jawab perempuan, jika perlu menyusui mereka.

Konsep keluarga bagi orang Mee adalah pemahaman keluarga inti (ayah, ibu dan anak) dan keluarga luas (kakek, nenek, paman bibi dsb). Relasi kekerabatannya tertutup. Masyarakat Mee tidak mengenal kasta. Strata lebih diwarnai status sosial seseorang dalam masyarakat. Ada dua status dalam masyarakat yaitu status tonowi dan daba. Status ini didasarkan pada kaum pria. Tonowi adalah priya yang kaya, punya banyak ternak, punya banyak istri, rumah yang besar dan kebun yang luas, seorang yang berpengaruh dan berwibawa. Sedangkan Daba adalah priya miskin, baik miskin ternak, mempunyai seorang istri atau duda, tidak berpengaruh luas dalam masyarakat.

Orang Mee memandang dunia sebagai sesuatu yang terbagi atas tiga bagian yaitu:

a. Dunia atas (epa wado), adalah lambang dunia kebaikan, dunia arwah nenek moyang; disebut juga sebagai tene wouda atau aya wouda. b. Dunia tengah, adalah dunia manusia dimana manusia harus mencari kehidupan yang aman dan berkelimpahan.

c. Dunia bawah atau dunia kejahatan, tempat roh-roh jahat berada.

Dalam kehidupan masyarakat tradisional, Suku Mee hidup berkelompok dan biasanya bermukim di dekat sungai. Oleh sebab itu mereka tidak memiliki kamar mandi dan WC dalam bangunan tradisionalnya, karena semua aktifitas tersebut dilakukan di sungai.

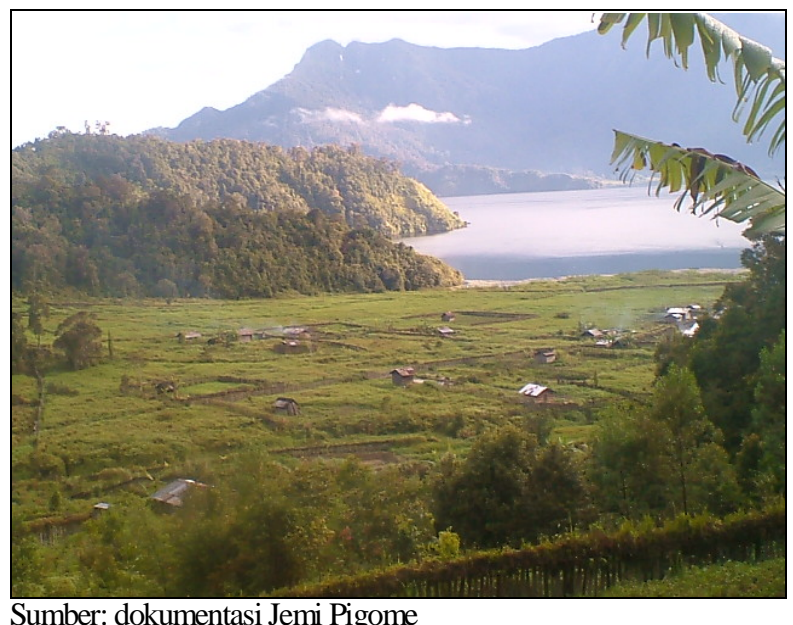

\section{Gambar 9. Pemukiman suku Mee mengelompok dan dekat sungai.}

Bangunan tradisional suku Mee terbuat dari bahan kayu, yang diruncingkan dan ditancapkan di tanah. Kayu-kayu tersebut sebagai pemikul atap dan sekaligus sebagai dinding. Sebagai pengikat digunakan tali rotan. Untuk atap menggunakan alang-alang. Sebagai penghangat di malam hari mereka membutuhkan tungku api di dalam bangunan, karena hembusan angin yang masuk melalui celah-celah tiang kayu dapat masuk dan mempengaruhi temperatur udara di dalam bangunan.

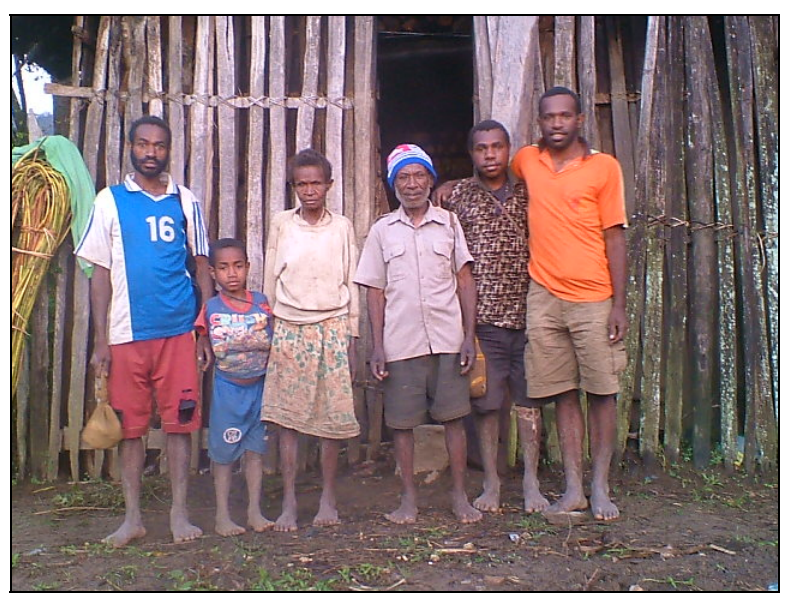

Sumber: dokumentasi Jemi Pigome

Gambar 10. Suku Mee di depan rumah tradisional 
Tata ruang rumah tradisional suku Mee memisahkan laki-laki dan perempuan dalam ruang yang berbeda. Laki-laki memiliki kedudukan yang lebih tinggi dari perempuan.
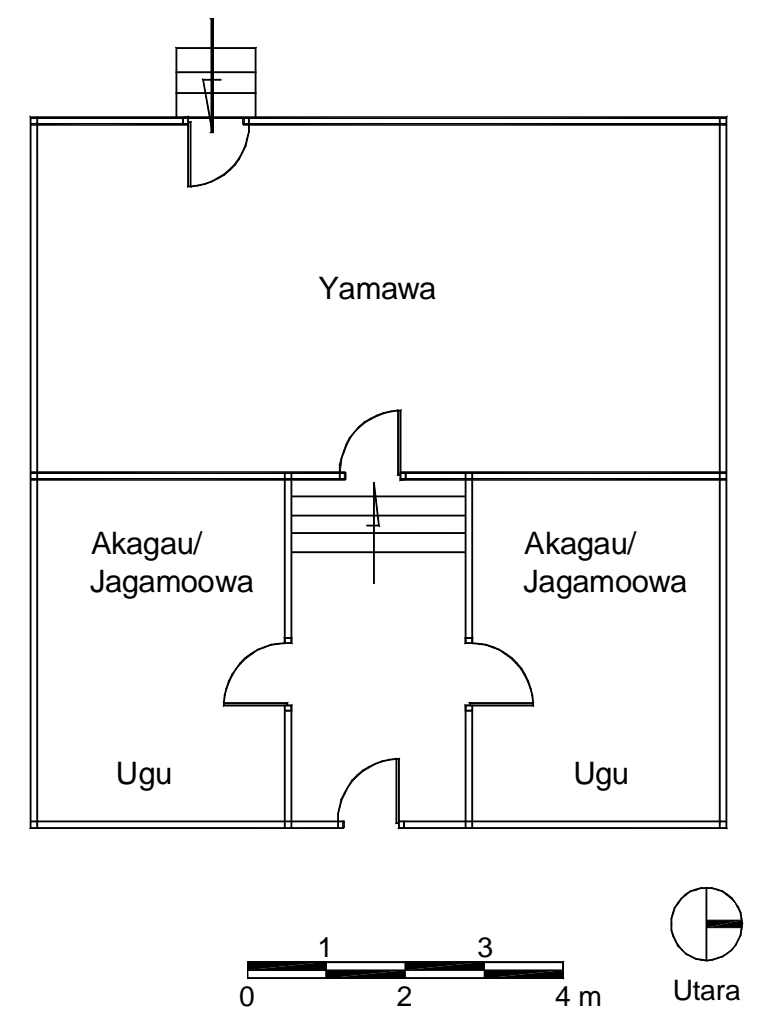

Keterangan:

$$
\begin{array}{ll}
\text { Yamawa } & =\text { tempat tidur laki-laki } \\
\text { Akagau/Jagamoowa } & =\text { tempat tidur perempuan } \\
\text { Ugu } & =\text { tungku }
\end{array}
$$

\section{Gambar 11. Rumah Adat Suku Mee}

Bagian atau ruang-ruang di dalam bangunan dalam bahasa Mee, dapat dilihat pada uraian berikut ini:

- Jagamoowa unoumida : Ruang Tidur Perempuan

- Yamawa unoumida

: Ruang Tidur Pria

- Meetouda

: Ruang Tamu

- Notanai dagu

: Ruang Makan

- Notayou owage

: Dapur

- Uwo onida dagu

: Kamar Mandi

- Bugida

: Kebun

- Ekinaka owa

: Kandang babi

- Uwo onida

: Sumur

Dalam perkembangannya, bahan bangunan yang digunakan untuk membangun rumah bagi suku Mee di kota Nabire adalah papan dan bukan batang kayu lagi. Papan disusun sebagai dinding dengan beberapa tiang kayu sebagai penyangga konstruksi atapnya. Atap menggunakan seng, karena distribusi bahan bangunan ke Nabire hanya mengandalkan kapal dan belum ada industri bahan bangunan di Nabire. Sedangkan seng memiliki resiko kerusakan yang kecil sat pengangkutan, sehingga dinilai sangat menguntungkan dan ekonomis bagi distributor bahan bangunan di Nabire.
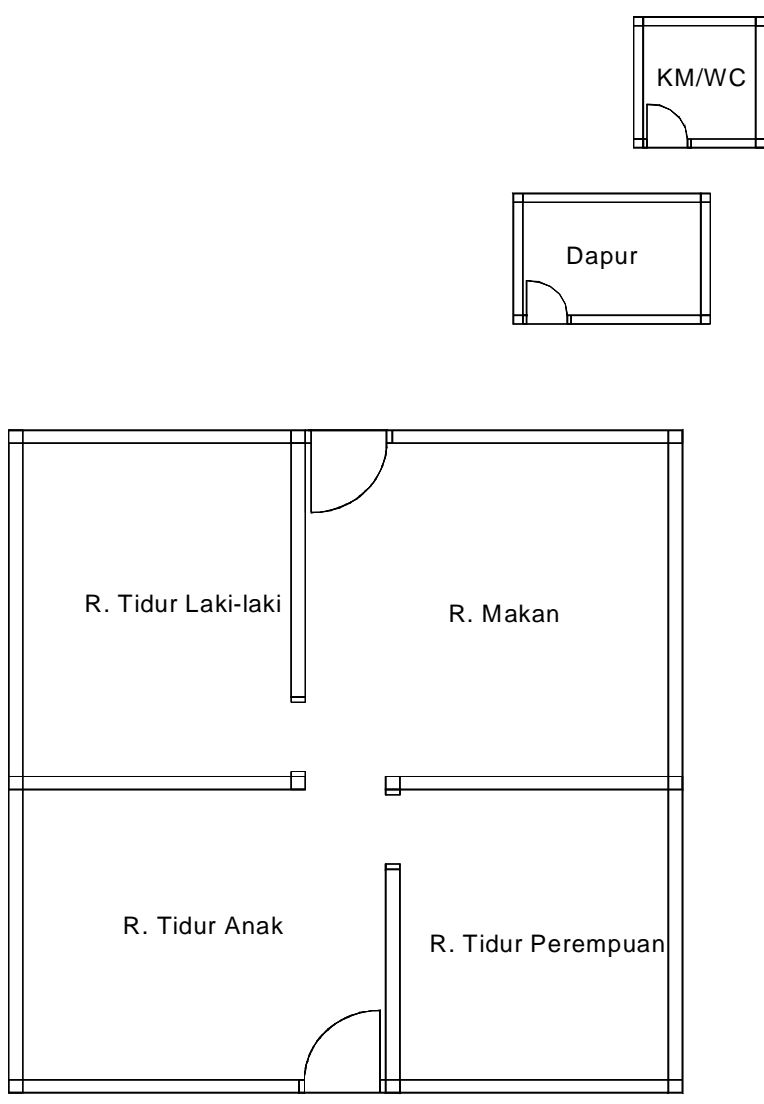

\section{Gambar 12. Rumah Vernakular Suku Mee}

Rumah vernakular suku Mee masih memegang teguh pemisahan kamar tidur laki-laki dan perempuan. Dapur dan KM/WC dipisahkan dari bangunan utama. KM/WC di luar bangunan menggambarkan tidak adanya keterkaitan bangunan dengan aktifitas yang biasanya dilakukan di sungai.

Selain Suku Mee terdapat juga suku pendatang di Nabire adalah suku Moni. Mereka tinggal di dekat kota Nabire. Karena pertimbangan ekonomi, tanah semakin mahal, bahan bangunan untuk rumah tradisional (yang memisahkan bangunan laki-laki dan perempuan) juga semakin mahal, maka masyarakat Moni membangun rumahnya dengan arsitektur masa kini yaitu arsitektur rumah-rumah baru yang dibangun pemerintah bagi para transmigran. Tampak bangunan seperti rumah pada umumnya, namun tata ruang dalamnya masih dipertahankan dengan konsep arsitektur tradisional. Pemisahan dapur, kandang babi dan gudang. Pada bentuk rumah masyarakat asli kandang babi, dapur dan gudang menjadi satu dengan rumah/bangunan perempuan. 


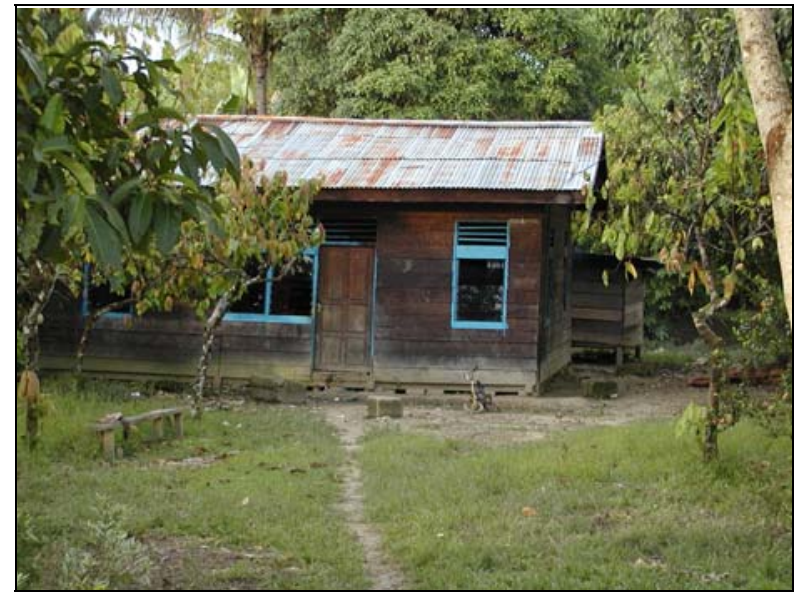

Gambar 13. Rumah Vernakular Suku Moni

Dalam kawasan pemukiman, mereka memiliki bangunan yang diberi nama Ugay, yaitu bangunan tempat berdansa para muda-mudinya. Dengan masuknya agama Katolik, maka peran Ugay digantikan oleh gereja sebagai tempat pesta rohani

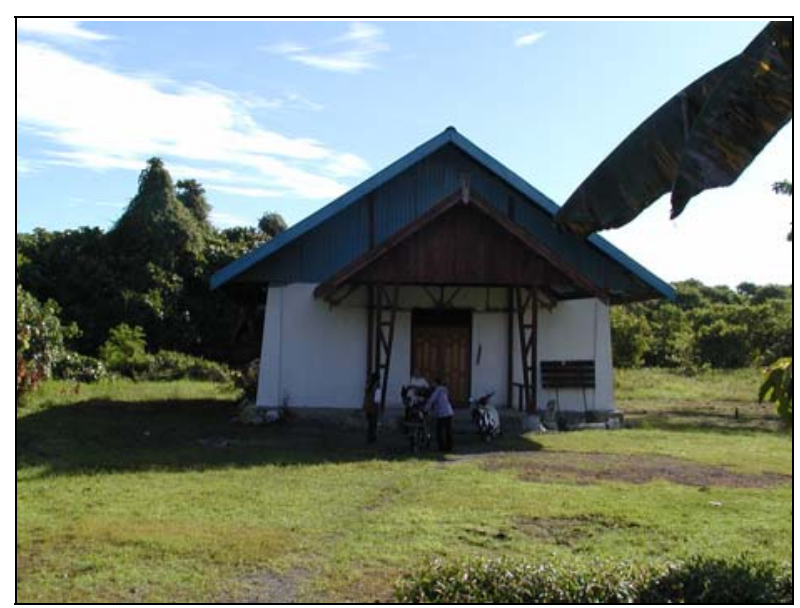

Gambar 14. Gereja sebagai “Ugay” rohani

Rumah tradisional suku Moni biasanya berupa rumah panggung. Pemisahan laki-laki dan perempuan juga dikenal di suku ini. Dapur dan Kamar mandi juga diletakkan di luar bangunan utama. Kebiasaan berperang, disikapi dengan bentuk rumah berdinding rangkap pada fasade bangunan depannya. Hal ini dimaksud sebagai perlindungan bagi penghuni dari serangan musuh. Pintu masuk diletakkan di samping untuk mempersulit masuknya musuh ke dalam rumah. Pada bangunan vernakular, keinginan untuk membangun dinding rangkap di fasade depan bangunan masih ada. Jika tanah yang dimiliki satu keluarga cukup besar, maka pemisahan antara lakilaki dan perempuan dapat dilakukan dengan pemisahan bangunannya. Ada bangunan untuk lakilaki dan ada bangunan untuk perempuan. Anak lakilaki akan mengikuti ayahnya dan anak perempuan akan mengikuti ibunya.

Bahan bangunan yang dipilih, mengikuti pertimbangan ekonomi dan efisiensi waktu serta pengerjaannya. Papan kayu dengan atap seng mendominasi bahan bangunan rumah tinggal suku Moni ini juga.

Bagian atau ruang di dalam bangunan dalam bahasa suku Moni dapat dilihat pada uraian berikut ini:

- Paneiyage : Ruang Tidur Perempuan

- Juiyage : Ruang Tidur Pria

- Tamuiyage : Ruang Tamu

- Hoganuaiyage : Ruang Makan

- Migaiyage : Dapur

- Duambuguaiyage : Kamar Mandi

- Indo : Kebun

- Wogoiyage : Kandang babi

- Utogopa : Sumur

- Usatawaiyage : Rumah besar
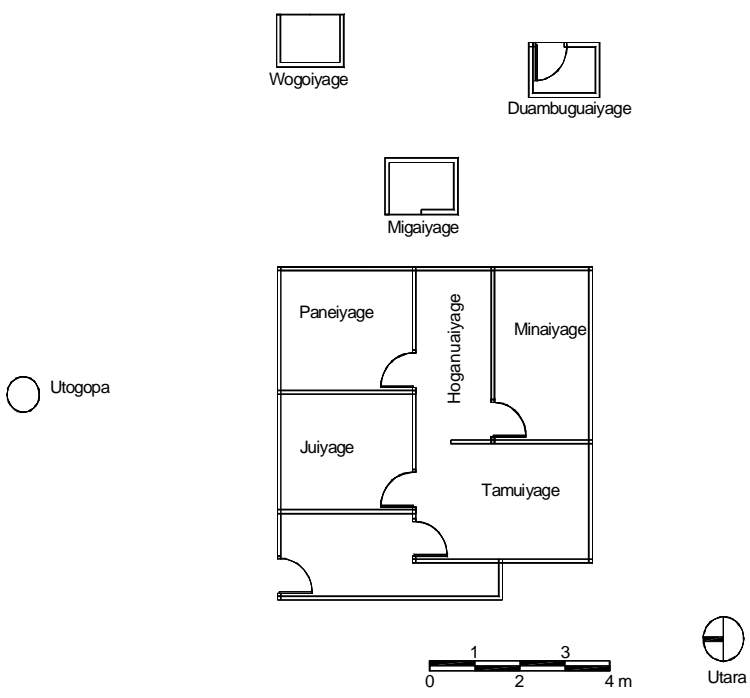

Gambar 15. Rumah Adat Suku Moni

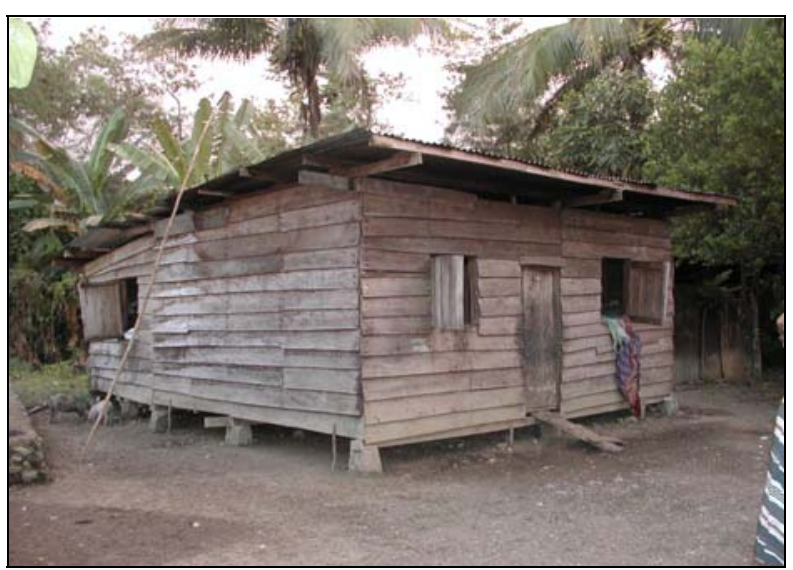

Gambar 16. Rumah Vernakular Suku Moni

\section{Kondisi Nabire Pasca Gempa}

Saat ini masih banyak rumah-rumah di pinggir kota Nabire belum tersentuh program bantuan perbaikan rumah pasca gempa dari pemerintah. Akibatnya rumah-rumah tersebut tetap dalam kondisi 
yang memprihatinkan. Kemampuan ekonomi masyarakat Nabire sendiri yang lemah mengakibatkan ketidakmampuan untuk memperbaiki sendiri rumah mereka. Akibatnya banyak yang masih tidur di tenda, walaupun gempa sudah berlalu 2 tahun yang lalu. Kerusakan yang terjadi pada rumah diakibatkan karena gaya lateral ke samping, sehingga rumah mengalami deformasi bentuk. Beban atap yang berat mengakibatkan kemiringan atap lebih diperparah.

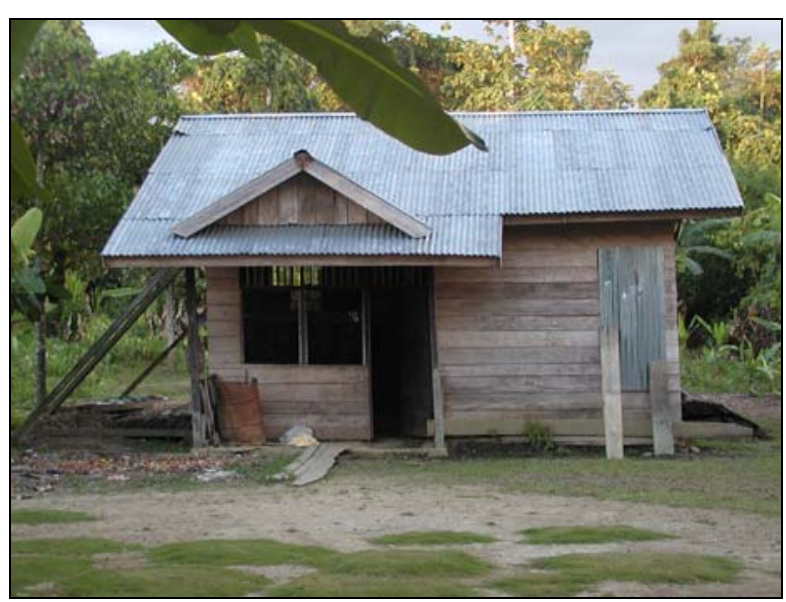

Gambar 17. Rumah Terkena Gempa

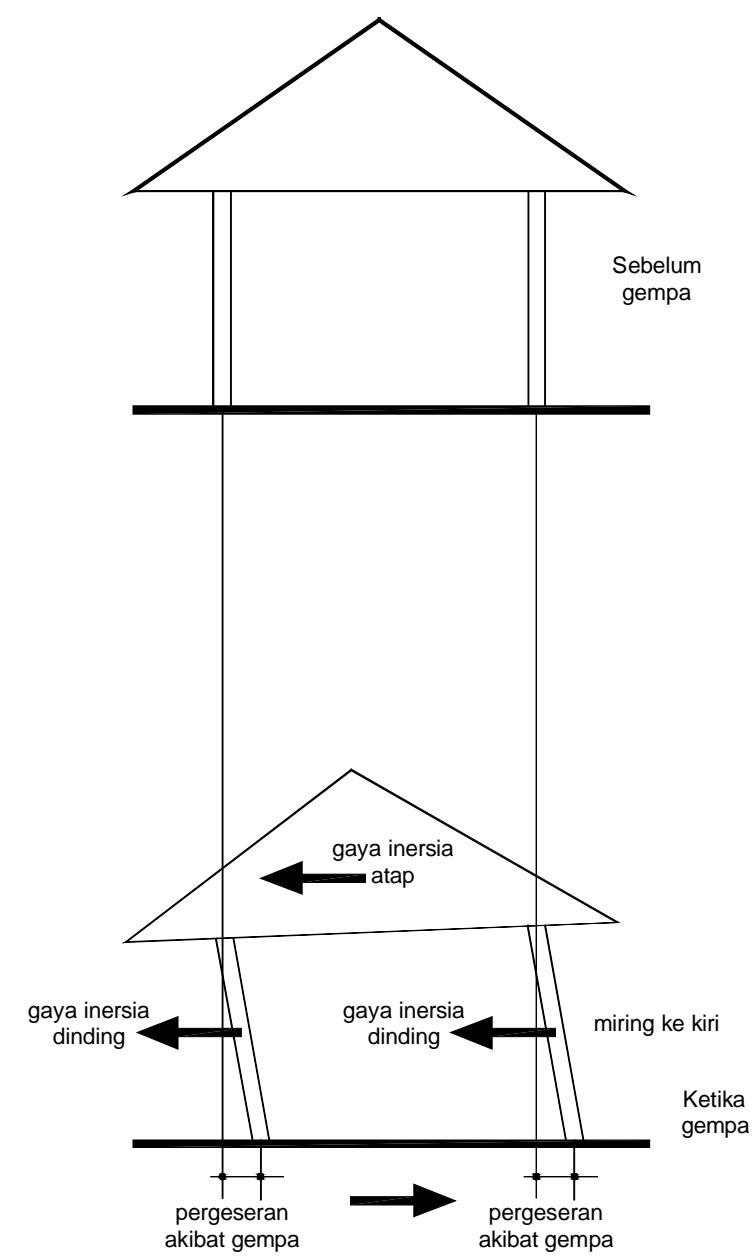

Gambar 18. Akibat Gempa Terjadi Gaya Lateral Yang Membuat Bangunan Roboh
Rumah tersebut tidak layak huni lagi, karena membahayakan jika terjadi gempa susulan. Resiko bangunan roboh dan atap runtuh merupakan kemungkinan yang akan terjadi, manakala ada getaran yang membuat dinding pemikul bergeser.
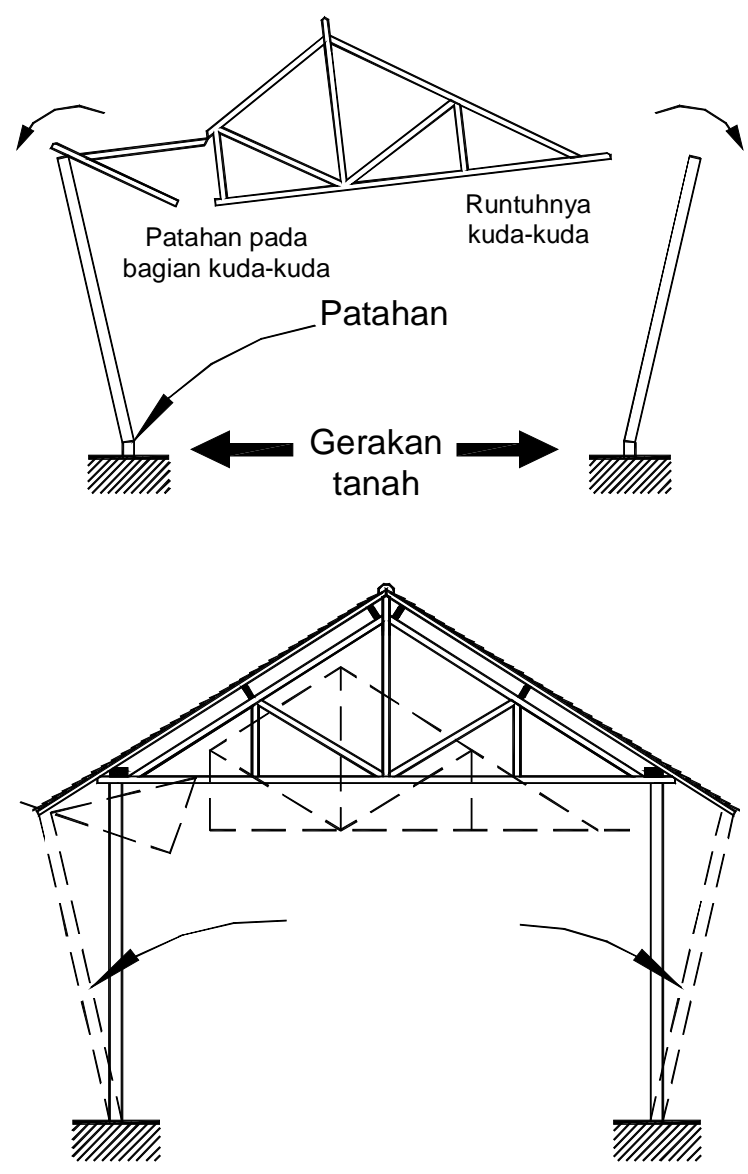

Gambar 19. Bergesernya Dinding Mengakibatkan Patah Dan Robohnya Atap

Untuk menghasilkan bentuk bangunan yang tahan gempa, perlu dipikirkan bentuk konfigurasi bangunannya. Bentuk konfigurasi struktur bangunan yang cocok untuk menahan gaya lateral dinamik gempa antara lain adalah:

- Bentuk denah bangunan yang sederhana dan simetris

- Kekakuan antar tingkat bangunan seragam atau mendekati seragam

- Bila bentuk denah tidak sederhana perlu diadakan pemisahan struktur sehingga bentuk menjadi kembali sederhana

- Sistem sambungan benar-benar rigid dan kaku

- Struktur bangunan harus lengkap yaitu ada sloof, kolom dan ring balk dengan ikatan sambungan yang kaku dan homogen.

Kerusakan akibat gempa yang terjadi di Nabire terutama disebabkan oleh: 
- Ketidak kokohan struktur dan konstruksi bangunan

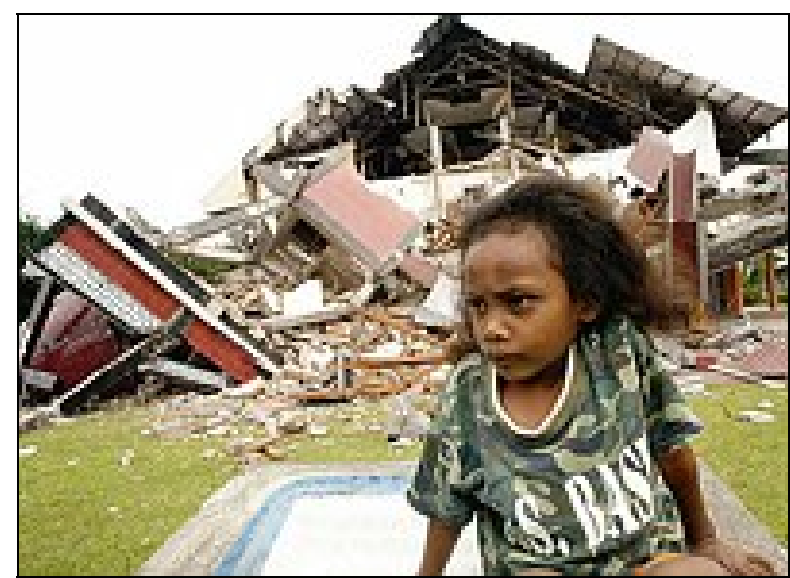

Gambar 20. Ketidak Kokohan Struktur dan Konstruksi Bangunan

- Sistem sambungan yang tidak rigid

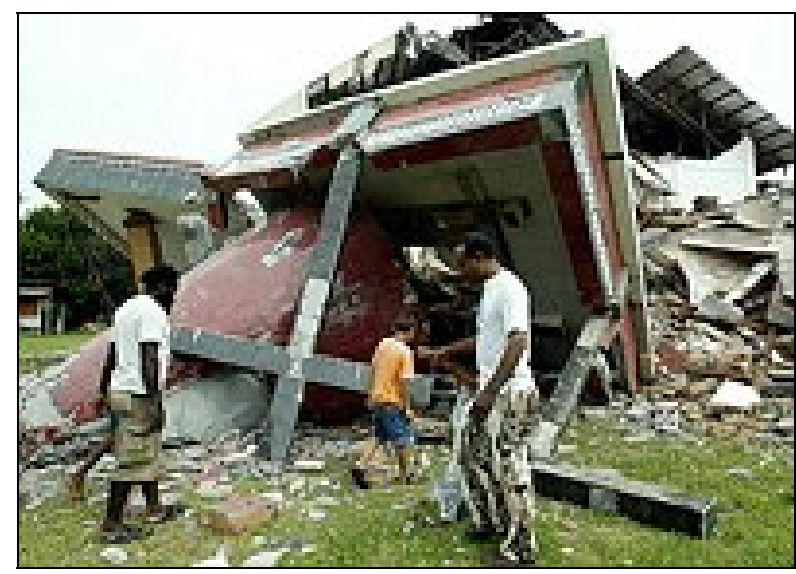

Gambar 21. Sistem Sambungan yang Terlepas

\section{PENUTUP}

Mencermati kearifan arsitektur tradisional yang mengkaitkan hubungan antara mikrokosmos (bangunan itu sendiri beserta penghuninya) dan makrokosmosnya (lingkungan alam sekitar), maka pembangunan rumah penampungan korban bencana harus memikirkan pula konsep filosofi tersebut. Keterkaitan antara makrokosmos dan mikrokosmos tercermin dengan bangunan yang ramah lingkungan dan iklim setempat dengan memperhatikan aspek temperatur, kelembaban udara, pergerakan udara, curah hujan dan radiasi matahari. Selain itu kekokohan struktural akan dapat meminimalisir kemungkinan kecelakaan akibat robohnya bangunan. Bangunan penampungan korban bencana alam ini sangat dibutuhkan tidak hanya oleh masyarakat Nabire namun untuk masyarakat luas dengan memperhatikan aspek manusia sebagai penghuninya.
Bangunan tersebut direncanakan dengan pertimbangan; cepat bangun, memperhatikan manusia sebagai penghuni, memperhitungkan iklim dan lingkungan sekitar, kinerja bangunan yang baik dan mencerminkan arsitektur vernakular yang dapat diterima oleh masyarakat setempat.

\section{DAFTAR PUSTAKA}

Rapoport, A., 1969, House, Form and Culture, London, Prentice-Hall International, Inc

Rapoport, A., 1969, Human Aspects of Urban Form, Towards a Man-Environment Approach to Urban Form and Design, Oxford England, Pergamon Press Ltd

, 1993, Etnografi Irian Jaya, Kelompok Peneliti Etnografi Irian Jaya, Irian jaya

Egenter, N., (n.d.), Architectural Anthropology, Volume 1: The Present Relevance of The Primitive in Architecture, (n.p) Structura Mundi

Koentjaraningrat, 1992, Irian Jaya: Membangun Masyarakat Majemuk, Jakarta, PT Penerbit Djambatan.

--, 1993, Masyarakat Terasing di Indonesia, Jakarta, Departemen Sosial dan Penerbit PT Gramedia Pustaka Utama

http://www.geocities.com/opm-irja/main23.htm

http://www.merelyscene.com/irian/image/mummy1.p apua.jpg

http://www.ritagoldengelman.com/images/irianjayafa mily.jpg

http://www.etm.pdx.edu/htliono/images/p190.jpg 